\title{
HUBUNGAN ANTARA KEMAMPUAN AWAL MATEMATIKA DAN MOTIVASI KULIAH MAHASISWA DENGAN HASIL BELAJAR STATISTIKA DASAR
}

\section{Mutmainah}

\section{STAIN Manado}

\begin{abstract}
Abstrak
Penelitian ini bertujuan untuk mengetahui: (1) hubungan antara kemampuan awal Matematika dengan hasil belajar statistika dasar mahasiswa STAIN Manado, (2) hubugan antara motivasi kuliah dengan hasil belajar statistika dasar mahasiswa STAIN Manado, dan (3) hubungan secara bersama-sama antara kemampuan awal matematika dan motivasi kuliah dengan hasil belajar statistika dasar mahasiswa STAIN Manado.
\end{abstract}

Metode penelitian yang digunakan adalah survey yang dilakukan pada 50 mahasiswa melalui teknik pengambilan sampel proporsional dan acak (proportional random sampling) pada 73 mahasiswa. Pengumpulan data penelitian hasil belajar statistika dasar dan kemampuan awal matematika di lakukan dengan menggunakan instrumen tes hasil belajar berbentuk essay, dan data motivasi kuliah di kumpulkan dengan menggunakan angket skala lima.

Analisis data menggunakan analisis regresi dan korelasi ganda. Hasil penelitian menunjukkan bahwa: (1) terdapat hubungan positif, kuat dan berarti antara kemampuan awal matematika dengan hasil belajar statistika dasar, dengan kontribusi sebesar $82,81 \%$; (2) terdapat hubungan positif, kuat, dan signifikan antara motivasi kuliah dengan hasil belajar statistika dasar dengan kontribusi sebesar 49,84\%; dan dan (3) terdapat hubunga positif, kuat, dan berarti secara bersama-sama antara kemampuan awal matematika dan motivasi kuliah dengan hasil belajar statistika dasar dengan kontribusi sebesar 72,2\%. Untuk itu disarankan pada dosen dalam 
menyajikan konsep materi statistika dasar agar: (1) meningkatkan kemampuan awal matematika mahasiswa dengan cara menjelaskan ulang konsep matematika diselasela perkuliahan atau memberikan pembekalan diluar jam perkuliahan baik secara individu maupun kelompok tergantung dari banyaknya mahasiswa yang memiliki kemampuan rendah, dengan terlebih dahulu mendeteksi kemampuan awal matematika mahasiswa sebelum proses perkuliahan di laksanakan misalnya melalui pemberian tes awal, (2) meningkatkan motivasi kuliah mahasiswa melalui pengelolaan perkuliahan berbasis mahasiswa, misalkan melalui penerapan modelmodel pembelajaran.

\section{Kata kunci : kemampuan awal matematika, motivasi kuliah dan hasil belajar}

\section{A. Pendahuluan}

Statistika dasar merupakan bagan dari salah satu mata kuliah keahlian yang diajarkan pada jenjang perguruan tinggi. Selain itu, statistika dasar dapat dipandang sebagai mata kuliah yang berdiri sendiri atau dapat juga di pandang sebagai mata kuliah baru yang merupakan mata kuliah terapan yang akan dapat di manfaatkan oleh mahasiswa dalam bidang penelitian khususnya bagi para mahasiswa yang memilih jalur skripsi. Karena itu, pola perkuliahan materi statistika dasar harus di tekankan pada kemampuan mahasiswa menguraikan dan menganalisis konsep-konsep seperti rumus-rumus dan data. Hal ini sesuai dengan tujuan perkuliahan statistika dasar yang terterah dalam kurikulum jurusan pendidikan agama islam (PAI) yaitu untuk membantu mahasiswa memecahkan permasalahan dalam pendidikan, terutama untuk kepentingan perencanaan pendidikan, administrasi pendidikan, evaluasi pendidikan, dan penelitian pendidikan.

Untuk mmencapai tujuan ini, maka mahasiswa harus menguasai konsep statistika dasar dan atuaran-aturan dalam matetatika. Hal ini sesuai yang dikatakan Kardi dan Nur bahwa teori statistika dasar banyak di nyatakan dalam notasi matematis, dan matematika yang di gunakan biasanya lebih rumit dari pada matematika yang di 
gunakan dalam bidang lainnya. Penguasaan mahasiswa terdapat konsep matematika dapat mengarahkan mahasiswa mencapai hasil belajar statistika dasar yang maksimal.

Namun kenyataan di lapangan menunjukan bahwa capaian hasil belajar statistika dasar mahasiswa sebagian besar masih belum menggembirakan. Hal ini dapat dilihat dari hasil ujian akhir mahasiswa. Setiap ujian akhir banyak mahasiswa yang gagal atau tidak lulus dan masih banyak di temui mahasiswa yang harus di remedial untuk memperbaiki hasil belajarnya.

Pencapaian hasil belajar mahasiswa yang rendah ini menunjukan bahwa mahasiswa mengalami kesulitan dalam menerapkan konsep statistika dasar dalam menyelesaikan masalah/ soal-soal statistika dasar. Untuk membantu mahasiswa yang mengalami kesulitan belajar maka dosen perlu menelususri berbagai faktor penyebab kesulitan belajar tersebut.

Beberapa faktor yang diprediksi berkaitan dengan kesulitan belajar mahasiswa dapat bersumber dari mahasiswa itu sendiri, dosen lingkungan, suasana kelas, dan sebagainya. Faktor yang bersumber dari mahasiswa misalnya, penguasaan konsep sebelumnya (kemampuan awal), motivasi kuliah, dan sebagainya. Faktor kemampuan awal mahasiswa ini perlu diperhatikan dosen, sebab mahasiswa akan mengalami kesulitan untuk mempelajari materi selanjutnya apabila di biarkan. Sebab kemampuan awal ini merupakan modal dalam mempelajari materi selanjutnya. Hal ini seperti yang di kemukakan Dick and Carrey bahwa kemampuan awal (entery behavior) merupakan pengetahuan dan keterampilan yang harus di miliki mahasiswa sebelum ia melanjutkan ke jenjang berikutnya. ${ }^{1}$

Kemampuan awal yang harus di miliki mahasiswa agar mudah mempelajari dan menguasai materi statistika dasar selain kemampuan tentang statistika dasar itu sendiri adalah kemampuan awal matematika. Mahasiswa yang memiliki kemampuan

${ }^{1}$ Dick and Carrey, The Systematic Design of Instruction. New york : Harper Collins Publishers, 1990) h,26. 
awal statistika dasar yang di dukung oleh kemampuan awal matematika yang tinggi akan lebih mudah menyerap materi yang di berikann dosen, sehingga mudah pula memecahkan dan menyelesaikan masalah/ soal dalam statistika dasar. Untuk itu, dosen harus memperhatikan kemampuan awal matematika setiap mahasiwa sebelum memulai proses perkuliahan.

Kemampan awal yang dimiliki mahasiswa perlu di ketahui dosen sebelum perkuliahan dimulai agar dosen dapat menyusun, mengolah, dan mengarahkan proses perkuliahan ke arah pencapaian tujuan perkuliahan yang telah di tetapkan. Hal ini selaras dengan pendapat Yamin bahwa pada awal atau sebelum masuk ke kelas memberi materi pengajaran kepada mahasiswa, ada tugas dosen yang tidak boleh di lupakan adalah mengetahui kemampuan awal mahasiswa. ${ }^{2}$ Sewaktu memberi materi kuliah di kelas dosen tidak akan kecewa dengan hasil yang di capai oleh mahasiswa. Untuk mendapat kemampuan awal mahasiswa dosen dapat menelusuri melalui pre tes baik secara tertulis maupun lisan.

Kemampuan awal mahasiswa perlu diketahui oleh dosen agar informasitersebut dapat di jadikan sebagai titik tolak untuk mengembangkan proses perkuliahan selanjutnya, sehingga tercapai tujuan instruksional yang pada akhirnya dapat meningkatkan hasil belajarnya. Gafur menganjurkan empat cara dalam memperoleh informasi kemampuan awal mmahasiswa, yaitu: (1) dengan menggunakan catatan-catatan atau dokumrn yang tersedia berupa nilai ijazah, NEM, nilai raport, nilai tes masuk, (2) dengan menggunakan tes prasyarat dan tes awal, (3) dengan menggunakan konsultasi individual, dan (4) menggunakan angket. ${ }^{3}$

Tes sebagai salah satu alat untuk menelusuri kemampuan awal peserta harus di susun sesuai dengan konsep statistika dasar yang akan di ajarkan. Untuk itu dapat di gunakan acuan penyusunan tes prasyarat dalam ranah kognitif sesuai anjuran 60

2 Yamin, Strategi Pembelajaran Berbasis Kompetensi, ( Jakarta: Gaun Persada Press,2009) h,

${ }^{3}$ Gafur. Desain Instruksional (Solo: Tiga Serangkai,1989) h,60 
Bloom yang mampu mengungkap pengetahuan (C1) pemahaman (C2), penerapan (C3), analisis( C4) sintesis (C5), dan evaluasi (C6).

Selanjutnya, Gafur mengatakan bahwa penyusunan program perkuliahan yang baik memerlukan dua macam informasi, yaitu (1) tujuan instruksional khusus, dan (2) kemampuan awal mahasiswa. Tujuan instruksional khusus adalah kemampuan, keterampilan dan sikap yang harus di miliki oleh mahasiswa manakala ia telah selesai mengikuti suatu program perkuliahan. Sedangkan kemampuan awal mahasiswa adalah pengetahuan dan keterampilan yang relevan yang telah ia miliki pada saat akan mulai mengikuti suatu program perkuliahan. ${ }^{4}$

Faktor lain dalam diri mahasiswa yang di prediksi berkaitan dengan hasil belajar statistika dasar adalah moivasi kuliahnya. Mahasiswa yang memiliki motivasi kuliah akan senantiasa tergerak hatinya untuk mencari informasi yang berkaitan dengan permasalahan yang di hadapi pada perkuliahan statistika dasar, berupaya untuk menyelesaikan permasalahan tersebut, melaksanakan tugas-tugas dengan senang hati, dan berupaya mencapa hasil belajar yang maksimal. Hal ini sesuai dengan pendapat Asrori bahwa motivasi merupakan: (1) dorongan yang timbul ke dalam diri seseorang, secara di sadari atau tidak di sadari, untuk melakukan tindakan dengan tujuan tertentu; (2) usaha-usaha yang dapat menyebabkan seseorang atau kelompok orang tertentu tergerak melakukan sesuatu karena ingin mencapai tujuan yang ingin di capai. ${ }^{5}$

Good dan Brophy menggolongkan tentang moivasi didasarka atas terbentuknya motif-motif tersebut yaitu: (1) motif bawaan dan (2) motif yang di pelajari. Motif bawaan sudah ada sejak di lahirkan tidak perlu di pelajari. Misalnya,

\footnotetext{
${ }^{4}$ Ibid, Gafur, h,57

${ }^{5}$ Asrori, Psikologi Pembelajaran.(Bandung: Wacana Prima,2007) h,183
} 
makan, minum, dan seksual. Motif yang kedua adalah motif yang timbul karena kedudukan atau jabatan. ${ }^{6}$

Selanjutnya, menurut Hamalik motivasi dapat di definisikan sebagai tenaga pendorong atau penarik yang menyebabkan adanya tingkah laku kearah suatu tujuan tertentu. Motivasi adalah dorongan internal dan eksternal dalam diri seseorang untuk mengadakan perubahan tingkah laku, yang mempunyai indikator sebagai berikut: (1) adanya hasrat dan keinginan melakukan kegiatan, (2) adanya dorongan dan kebutuhan melakukan kegiatan, (3) adanya harapan dan cita-cita, (4) penghargaan dan penghormatan atas diri, (5) adanya lingkungan yang baik, (6) adanya kegiatan yang menarik. ${ }^{7}$

Ada beberapa ciri mahasiswa yang memiliki motivasi kuliah yang tinggi, yang dapat dikenali pada saat proses perkuliahan berlangsung di kelas, sebagaimana dikemukakan Brown sebagai berikut: (1) Tertarik kepada dosen, artinya tidak membenci atau bersikap acuh tak acuh, (2) tertarik pada mata kuliah yang di ajarkan, (3) mempunyai antusias yang tinggi serta mampu mengendalikan perhatiannya terutama terhadap dosen, (4) ingin selalu bergabung dalam kelompok kelas, (5) ingin identitasnya dirinya di akui orang lain, (6) selalu mengingat kuliah dan mempelajarinya kembali, (7) selalu terkontrol oleh lingkungannya. ${ }^{8}$ Pendapat yang senada di kemukakan oleh Slameto bahwa ciri-ciri motivasi pada diri seseorang adalahh (1) tekun dalam menghadapi tugas atau dapat bekerja secara terus menerus dalam waktu lama, (2) ulet menghadapi kesulitan dan tidak mudah putus asa, tidak cepat puas akan prestasi yang di peroleh, (3) menunjukan minat yang besar terhadap

\footnotetext{
${ }^{6}$ Good dan Brophy, Educational Psychologi, A. Realistic Aproach, (New York: Longman 1990) h, 360

${ }^{7}$ Hamalik, Proses Belajar Mengajar. (Bandung: Bumi Aksara,2001) h,25

${ }^{8}$ Brown lihat Uno,Desain Pembelajaran, (Gorontalo: Nurul Jannah,2008) h,194
} 
macam-macam masalah belajar, (4) tidak cepat bosan dengan tugas-tugas rutin, (5) dapat mempertahankan pendapatnya, (6) senang mencari dan memecahkan masalah. ${ }^{9}$

Motivasi kuliah mahasiswa ini akan tumbuh dan berkembang apabila dosen dalam mengelolah perkuliahan senantiasa berorientasi pada mahasiswa yang belajar (student learning) bukan pada penuntasan materi kuliah. Pola perkuliahan seperti ini mampu membangkitkan aktivitas mahasiswa selama proses perkuliahan berlangsung, sehingga pencapaian hasil belajar mahasiswayang maksimal mudah tercapai.

Bebrapa faktor yang di kemukakan di atas perlu mendapat perhatian dosen. Sebab, mahasiswa yang memiliki kemampuan awal matematika (menguasai konsepkonsep matematika yang berkaitan dengan konsep statistika dasar) dan di dukung adanya motivasi kuliah akan sangat membantu mahasiswa mencapai hasil belajar statistika dasar yang maksial.

\section{Metode penelitian}

Penelitian ini dilaksanakan di STAIN Manado. Mahasiswa yang di jadikan sampel dalam penelitian ini adalah mahasiswa jurusan PAI STAIN Manado angkatan 2010/2011 sebanyak 50 orang yang tersebar pada 4 kelas. Teknik pengambilan sampel menggunakan teknik "proporsional random sampling". Dengan demikian ada dua tahap teknik pengambilan sampel dalam penelitian ini yakni: (1) di ambil secara proporsional, dan (2) random

Selanjutnya metode dalam penelitian ini adalah metode survey dengan teknik korelasional. Teknik ini digunakan untuk melihat hubungan secara empirik dari variabel kemampuan awal matematika $\left(\mathrm{X}_{1}\right)$ DAN MOTIVASI KULIAH $\left(\mathrm{X}_{2}\right)$ sebagai variabel bebas dan hasil belajar satistika dasar (Y) sebagai variabel tak bebas.

2. Teknik pengumpulan data

h, 106

\footnotetext{
${ }^{9}$ Slameto. Belajar dan Faktor-faktor yang Mempengaruhinya.( Jakarta: Rineka Cipta,2003)
} 
Ada tiga sumber data yang akan dijaring untuk keperluan penelitian ini, yaitu (1) data kemampuan awal matematika, (2) data motivasi kliah, dan (3) data hasil belajar statistika dasar. Data kemampuan awal matematika dan hasil belajar statistika dasar di kumpulkan dengan menggunakan instrumen tes berbentuk essay, dan data motivasi kuliah di kumpulkan dengan menggunakan angket/ kuisioner dengan lima kategori pilihan jawaban yaitu selalu dengan skor 5, sering dengan skor 4, kadang-kadang dengan skor 3, jarang dengan skor 2, dan tidak pernah dengan skor 1.

Instrumen penelitian yang digunakan dalam pengambilan data penelitian terlebih dahulu di uji coba lapangan untuk melihat validitas butir dan realibilitas instrumen. Untuk menguji validitas butir tes kemampuan awal matematika dan hasil belajar statistika dasar menggunakan validasi isi yaitu di kontrol melalui kisikisi instrumen. Untuk menghitung validitas butir instrumen motivasi kuliah (data kontinum) menggunakan rumus korelasi product moment dari pearson, ${ }^{10}$ dan untuk menghitung reliabilitas instrumen menggunakan rumus Apha Cronbach ${ }^{11}$.

Instrumen motivasi kuliah yang di gunakan untuk mengukur motivasi kuliah mahasiswa berisi 35 pernyataan. Berdasarkan hasil uji coba di peroleh 31 butir pernyataan di nyatakan valid dan 4 butir di nyatakan tidak valid (drop). Butir yang tidak sahih ini di keluarkan kemudian di hitung reliabilitas butir-butir ini. Hasil pengujian reliabilitas di peroleh nilai koefisien reliabilitas sebesar 0,87. Hasil penghitungan ini menunjukan instrumen motivasi belajar memiliki klasifikasi kepercayaan yang sangat tinggi. Dengan memperhatikan hasil pengujian validitas dan reliabilitas empiri, maka 31 butir pernyataan motivasi belajar mahasiswa memenuhi syarat untuk di jadikan sebagai instrumen pengumpul data penelitian.

\section{Teknik analisi data}

${ }^{11}$ Ibid, Arikunto h,193 
Analisis data yang di gunakan dalam penelitian ini terdiri atas dua bagian, yaitu analisis deskriptif dan analisis inferensial. Analisis deskriptif dalam data penelitian ini meliputi perhitungan rerata, median, modus, standar deviasi, dan di tampilkan dalam tabel distribusi frekuensi, sedangkan analisis inferensial meliputi pengujian hippotesis penelitian. Uji ststistika dasar yang di gunakan adalah regresi dan korelasi ganda.

Ada tiga hipotesis penelitian yang di uji dalam penelitian ini. Untuk pengujian hipotesis pertama dan kedua di gunakan teknik analsis regresi dan korelasi sederhana, sedangkan untuk pengujian hipotesis ketiga digunakan teknik analisis regresi dan korelasi ganda.

\section{Hipotesis statistik}

Pasangan hipotesis statistik yang di uji dalam penelitian ini adalah:

1. $\mathrm{H} 0: \mathrm{P}_{\mathrm{y} 1}=0$

$\mathrm{H} 1=\mathrm{P}_{\mathrm{y} 1}>0$

2. $\mathrm{HO}: \mathrm{P}_{\mathrm{y} 2}=0$

$\mathrm{H} 1: \mathrm{P}_{\mathrm{y} 2}>0$

3. $\mathrm{H} 0: \mathrm{R}_{\mathrm{y} 12}=0$

$\mathrm{H} 1: \mathrm{R}_{\mathrm{y} 12}>0$

Keteranan :

$\mathrm{H}_{0}=$ hipotesis nol

$\mathrm{H}_{1}=$ Hipotesis alternatif

$\mathrm{P}_{\mathrm{y} 1}=$ koefisien korelasi populasi antara kemampuan awal matematika dengan hasil belajar statistika dasar mahasiswa STAIN Manado

$\mathrm{P}_{\mathrm{y} 2}=$ koefisien korelasi populasi antara motivasi kuliah dengan hasil belajar statistika dasar mahasiswa STAIN Manado 
$\mathrm{R}_{\mathrm{y} 12}=$ koefisien korelasi populasi secara bersama-sama antara kemampuan awal matematika dan motivasi kuliah dengan hasil belajar statistika dasar mahasiswa STAIN Manado

\section{B. Hasil penelitian dan pembahasan}

\section{a. Data hasil belajar statistik}

Berdasarkan hasil tes yang di berikan pada 50 orang mahasiswa di peroleh skor minimum 50 dan maksimum 96.

Dari hasil tes yang di berikan di peroleh nilai rata-rata (M) sebesar 76,82; median (Me) sebesar 90,23; modus (Mo) sebesar 87,68; dan standar deviasi (SD) sebesar 14,59. Nilai skor rata-rata maka dapat dikatakan terdapat 19 orang mahasiswa (38\%) memperoleh skor hasil belajar statistika dasar di sekitar ratarata, 1 orang mahasiswa (2\%) memperoleh skor di atas rata-rata, dan 30 orang mahasiswa (42\%) memperoleh skor di bawah rata-rata. Hasil pengujian menunjukan bahwa hasil belajar statistika dasar sebagian besar berada pada rentangan skor di bawa rata-rata. Temuan ini berarti bahwa hasil belajar statistika dasar mahasiswa berada pada kategori cukup tinnggi.

\section{b. Data kemampuan awal matematika}

Berdasarkan hasil tes yang di berikan pada 50 orang mahasiswa di peroleh skor minimum 20 dan maksimum 95.Dari hasil tes yang diberikan diperoleh nilai rata-rata (Mo) sebesar 55,50; median (Me) sebesar 50,5; modus (Mo) sebesar 44,8; dan standar deviasi (SD) sebesar 21,19.Dengan memperhatikan skor ratarata,ada 11 orang mahasiswa (22\%) memperoleh skor kemampuan awal matematika disekitar rata-rata,dan 16 orang mahasiswa (32\%) memperoleh skor dibawah rata-rata.Hasil pengujian menunjukkan bahwa kemampuan awal matematika mahasiswa sebagian besar berada pada rentangan skor rata-rata keatas.Temuan ini mengindikasikan bahwa kemampuan awal matematika mahasiswa berada pada kategori tinggi. 


\section{c. Data Motivasi Kuliah}

Berdasarkan hasil tes yang diberikan pada 50 orang mahasiswa diperoleh skor minimum 78 dan maksimum 139.Dari hasil tes diperoleh nilai rata-rata (M) sebesar 110,92; median (Me) sebesar 111,42;modus (Mo) sebesar 110,50; dan standar deviasi (SD) sebesar 14,59.Dengan memperhatikan rata-rata maka dapat dikatakan bahwa terdapat 13 orang mahasiswa (26\%) memperoleh skor motivasi kuliah disekitar rata-rata 22 orang mahasiswa (44\%) memperoleh skor di atas rata-rata dan 15 orang mahasiswa (30\%) memperoleh skor di bawah rata-rata. Hasil pengujian menunjukan bahwa motivasi kuliah mahasiswa sebagian besar berada pada rentangan skor rata-rata ke atas. Temuan ini menindikasikan bahwa motivasi kuliah mahasiswa berada pada kategori tinggi.

\section{Pengujian persyaratan analisis}

Berdasarkan hasil pengujian persyaratan analisis di peroleh hasil pengujian normalitas data melalui galat taksiran regresi dan homogenitas varians menunjukan bahwa uji persyaratan analisis regresi dan korelasi ganda di penuhi

\section{Pengujian Hipotesis}

1. Hubungan antara kemampuan awal matematika $\left(X_{1}\right)$ dengan hasil belajar statistika dasar (Y) mahasiswa STAIN Manado.

Hipotesis pertama yang di ajukan adalah: "terdapat hubungan positif anatara kemampuann awal matematika dengan hasil belajar statistika dasar mahasiswa STAIN Manado pada mata kuliah statistika dasar".

Berdasarkan hasil perhitungan analisis regresi sederhana dalam variabel kemampuan awal matematika $\left(\mathrm{X}_{1}\right)$ dengan hasil belajar statistika dasar (Y) menghasilkan arah regresi $b$ sebesar - 0,058 dan konstanta $a$ sebesar 80,039. Dengan demikian bentuk hubungan antara variabel kemampuan awal matematika $\left(\mathrm{X}_{1}\right)$ dengan 
hasil belajar statistika dasar (Y) digambarkan oleh model atau persamaan regresi variabel $\mathrm{Y}=80,039-0,058 \mathrm{X}_{1}$. Model regresi $\mathrm{Y}=80,039-0,58 \mathrm{X}_{1}$ Ini agar dapat di gunakan untuk menarik kesimpulan penelitian, harus memenuhi syarat signifikansi (keberartian) dan linearitas regresi,di gunakan uji F. Hasil hitungan uji signifikansi regrensi di peroleh nilai $F$ hitung sebesar 2918,40. Nilai $F$ tabel pada taraf signifikansi $\alpha$ $=0,05$ dengan derajat bebas $(\mathrm{db})$ pembilang 1 dan derajat bebas $(\mathrm{db})$ penyebut 48 sebesar 4,04. Karena nilai $\mathrm{F}_{\text {hitung }}=2918,40>\mathrm{F}_{\text {tabel }}=4,04$ pada taraf signifikansi $\alpha$ $=0,05$ maka model regresi sederhana $\bar{Y}=\bar{Y}=80,039-0,058 X_{1}$ dinyatakan sangat signifikan.

Temuan ini memberikan arti bahwa apabila kemampuan awal matematika mahasiswa $\left(\mathrm{X}_{1}\right)$ meningkatkan sebesar 1 unit, maka hasil belajar statistika dasar mahasiswa STAIN Manado (Y) cenderung meningkat sebesar 80,0448 pada konstanta 80,039. Dengan kata lain hasil belajar statistika dasar mahasiswa di tentukan pula oleh kemampuan awal matematika yang dimiliki.

Hasil analisis korelasi sederhana antara kemampuan awal matematika $\left(\mathrm{X}_{1}\right)$ dengan hasil belajar statistika dasar $(\mathrm{Y})$ di peroleh nilai koefisien korelasi $\left(\mathrm{r}_{\mathrm{y} 1}\right)$ sebesar 0,13. Nilai koefisien korelasi ini menunjukan bahwa hubungan antara kemampuan awal matematika dengan hasil belajar statistika dasar mahasiswa STAIN Manado adalah positif dan cukup kuat.

Temuan ini membenarkan hipotesis penelitian yang di ajukan terdapat hubungan positif antara kemampuan awal matematika dengan hasil belajar statistika dasar mahasiswa STAIN Manado. Dengan kata lain, makin tinggi kemampuan awal matematika mahasiswa, maka makin tinggi pula hasil belajar statistika dasar. Hubungan ini ternyata merupakan hubungan yang signifikan. Hal ini sesuai dengan hasil pengujian signifikansi (keberartian) koefisien korelasi antara kemampuan awal matematika dan hasil belajar statistika dasar melalui uji - t. Hasil pengujian di peroleh nilai $\mathrm{t}_{\text {hitung }}$ sebesar 0,91 . Nilai $\mathrm{t}$ tabel pada taraf signifikansi $\alpha=0,05$ dengan 
derajat kebebasan $(\mathrm{db})=48$ sebesar 2,01 karena nilai $\mathrm{t}_{\text {hitung }} 0,91>\mathrm{t}$ tabel $=2,01$ maka $_{0}$ di tolak. Ini berarti menerima $\mathrm{H}_{1}$ yang mengatakan bahwa koefisien korelasi antara kemampuan awal matematika dengan hasil belajar statistika dasar signifikan.

Hubungan positif, kuat dan signifikan antara kemampuan awal matematika $\left(\mathrm{X}_{1}\right)$ dengan hasil belajar statistika dasar (Y) mahasiswa STAIN Manado ini menghasilkan koefisien determinasi $\left(\mathrm{r}_{\mathrm{y} 1}{ }^{2}\right)$ sebesar $(0,91)^{2}=0,8281$. Hal ini berarti bahwa $82,81 \%$ variasi yang terjadi pada hasil belajar statistika dasar (Y) dapat di jelaskan oleh variasi kemampuan awal matematika $\left(\mathrm{X}_{1}\right)$ melalui model regresi $\mathrm{Y}=80,039-0,058$ $\mathrm{X}_{1}$. Dengan kata lain bahwa kontribusi yang di sumbangkan oleh variabel kemampuan awal matematika terhadap hasil belajar statistika dasar mahasiswa STAIN Manado sebesar 82,81\%

\section{Hubungan antara motivasi kuliah $\left(\mathbf{X}_{2}\right)$ dengan hasil belajar statistika dasar (Y) mahasiswa STAIN Manado}

Hipotesis kedua yang di ajukan dalam penelitian ini adalah : " terdapat hubungan positif antara motivasi kuliah dengan hasil belajar mahasiswa STAIN Manado”.

Hasil perhitungan regresi sederhana data variabel motivasi kuliah $\left(\mathrm{X}_{2}\right)$ dengan hasil belajar mahasiswa STAIN Manado pada mata kuliah statistika dasar (Y) menghasilkan arah regresi $b$ sebesar 0,0038 dan konstanta $a$ sebesar 76,40. Dengan demikian bentuk (model) hubungan antara variabel motivasi kuliah $\left(\mathrm{X}_{2}\right)$ dengan hasil belajar statistika dasar (Y) di gambarkan oleh model / persamaan regresi Y $=76,40+$ $0,0038 \mathrm{X}_{2}$.

Model regresi sedarhana $\mathrm{Y}=76,40+0,0038 \mathrm{X}_{2}$ sebelum di gunakan unuk menarik kesimpulan penelitian, harus memenuhi syarat signifikansi dan linearitas regresi. Untuk mengetahui derajat signifikansi (keberartian) dan linearitas regresi, di gunakan uji F. Hasil penghitungan uji signifikansi regresi di peroleh nilai $F_{\text {hitung }}$ sebesar 0,0015. Nilai $F_{\text {tabel }}$ pada taraf signifikansi $\alpha=005$ dengan derajat bebas $(\mathrm{db})$ 
pembilang 1 dan derajat bebas $(\mathrm{db})$ penyebut 48 sebesar 0,04. Karena nilai $F_{\text {hitung }}<$ $\mathrm{F}_{\text {tabel }}$ maka $\mathrm{H}_{0}$ di tolak. Ini berarti menerima $\mathrm{H}_{1}$ yang menyatakan bahwa model regresi $\mathrm{Y}=76,40+0,0038 \mathrm{X}_{2}$ signifikansi. Model regresi ini ternyata signifikan karena nilai $F_{\text {hitung }}<F_{\text {tabel }}$ pada taraf sifnifikansi $\alpha=0,05$.

Hasil perhitungan uji linearitas regresi $\mathrm{Y}$ atau $\mathrm{X}_{2}$ di peroleh nilai $\mathrm{F}_{\text {hitung }}$ sebesar 1,06. Nilai $F_{\text {tabel }}$ pada taraf signifikansi $\alpha=0,05$ dengan derajat bebas $(\mathrm{db})$ pembilang 30 dan derajat bebas $(\mathrm{db})$ penyebut 18 sebesar 2,11. Karena nilai $F_{\text {hitung }}<F_{\text {tabel }}$ pada taraf signifikansi maka $\mathrm{H}_{0}$ di tolak. Ini berarti menerima $\mathrm{H}_{1}$ yang menyatakan bahwa persamaan regresi $\mathrm{Y}=76,40+0,0038 \mathrm{X}_{2}$ berbentuk "liear".

Hasil pengujian signifikansi (keberartian) dan linearitas regresi sederhana $\mathrm{Y}$ atas $\mathrm{X}_{2}$ menunjukan bahwa persamaan regresi $\mathrm{Y}=76,40+0,0038 \mathrm{X}_{2}$ menunjukan bahwa jika motivasi kuliah mahasiswa $\left(\mathrm{X}_{2}\right)$ meningkat sebesar 1 unit, maka hasil belajar statistika dasar (Y) mahasiswa STAIN Manado cenderung meningkat sebesar 76,4038 pada konstanta 76,40. Dengan kata lain bahwa hasil belajar statistika dasar mahasiswa dapat di tentukan oleh motivasi kuliah yang di miliki mmahasiswa.

Hasil analisis koefisien korelasi sederhana antara motivasi kuliah $\left(\mathrm{X}_{2}\right)$ dengan hasil belajar statiska dasar(Y) diperoleh nilai koefisien korelasi $\left(\mathrm{r}_{\mathrm{y}} 2\right)$ sebesar 0,706. Nilai koefisien korelasi ini menunjukan bahwa hubungan antara motivasi kuliah dengan hasil belajar statistika dasar mahasiswa STAIN Manado adalah positif dan kuat.

Temuan ini membenarkan hipotesis penelitian yang di ajukan yaitu terdapat hubungan positif antara motivasi kuliah dengan hasil belajar statistika dasar mahasiswa STAIN Manado. Dengan kata lain, makin tinggi motivasi kuliah mahasiswa, maka makin tinggi pula hasil belajar statistika dasar. Hubungan ini ternyata merupakan hubungan yang signifikan. Hal ini sesuai dengan hasil uji signifikansi (keberartian) koefisien korelasi antara motivasi kuliah dengan hasil belajar statistika dasar melalui uji-t. Hasil pengujian di peroleh nilai thitung sebesar 
7,592. Nilai tabel pada taraf signifikansi $\alpha=0,05$ dengan derajat kebebasan $(\mathrm{db})=48$

masing-masing sebesar 2,01. Karena nilai $t_{\text {hitung }}>\mathrm{t}_{\text {(tabel) }}$ maka $\mathrm{H}_{0}$ di tolak. Ini berarti menerima $\mathrm{H}_{1}$ yang menyatakan koefisien korelasi signifikan.

Hubungan positif dan kuat antara motivasi kuliah $\left(\mathrm{X}_{2}\right)$ dengan hasil belajar statistika dasar (Y) mahasiswa STAIN Manado menghasilkan koefisien detrminasi $\left(\mathrm{r}_{\mathrm{y} 2}{ }^{2}\right)$ sebesar $(0,706)^{2}=0,4984$. Hal ini berarti bahwa $49,84 \%$ variasi yang terjadi pada hasil belajar statistika dasar(Y) dapat dijelaskan oleh variasi motivasi kuliah ( $\mathrm{x}_{2}$ ) melalui persamaan regresi $\mathrm{Y}=76,40+0,0038 \mathrm{X}_{2}$.Dengan kata lain,konstribusi yang disumbangkan variabel motivasi kuliah terhadap hasil belajar statistika dasar mahasiswa STAIN Manado sebesar 49,84\%.

\section{Hubungan antara Kemampuan awal Matematika $\left(\mathrm{X}_{1}\right)$ dan motivasi kuliah $\left(\mathbf{X}_{2}\right)$ secara Bersama-sama dengan Hasil belajar statistika dasar (Y) mahasiswa STAIN Manado}

Hipotesis ketiga yang diajukan dalam penelitian ini adalah : "Terdapat hubungan positif secara bersama-sama antara kemampuan awal matematika dan motivasi kuliah dengan hasil belajar statistika dasar mahasiswa STAIN Manado”. Analisis yang digunakan untuk menguji hipotesis ini adalah analisis regresi dan korelasi ganda.

Hasil penghitungan uji regresi ganda diperoleh nilai koefisien arah regresi a sebesar 2,25 untuk variabel $\mathrm{X}_{1}$ (kemampuan awal matematika); koefisien arah regresi a sebesar -0,61 untuk variabel $\mathrm{X}_{2}$ (motivasi kuliah), dan konstanta $\mathrm{a}_{0}$ sebesar 19,61. Dengan demikian bentuk hubungan antara kemampuan awal matematika dan motivasi kuliah secara bersama-sama dengan hasil belajar statistika dasar mahasiswa STAIN Manado digambarkan oleh model/persamaan regresi $\mathrm{Y}=19,61+2,25 \mathrm{X}_{1}-$ $0,61 X_{2}$ 
Model regresi linear ganda $\mathrm{Y}=19,61+2,25 \mathrm{X}_{1}-0,61 \mathrm{X}_{2}$ sebelum digunaan untuk menarik kesimpulan penelitan, maka harus memenuhi signifikansi regresi. Untuk mengetahui signifikansi model regresi linear ganda, dilakukan melalui uji F. Hasil penghitungan diperoleh nilai $F_{\text {hitung }}$ sebesar 35,82. Nilai $F_{\text {tabel }}$ pada taraf signifikansi $\alpha=0,05$ dengan $\mathrm{db}$ pembilang $=2$ dan $\mathrm{db}$ penyebut $=47$ sebesar 3,19. Karena $F_{\text {hitung }}>F_{\text {tabel }}$ maka $\mathrm{H}_{0}$ di tolak. Ini berarti menerima $\mathrm{H}_{1}$ yang menyatakan bahwa model regresi ganda $\mathrm{Y}=19,61+2,25 \mathrm{X}_{1}-0,61 \mathrm{X}_{2}$ signifikan. Model regresi ganda ini ternyata sangat signifikan karena nilai $F_{\text {hitung }}>F_{\text {tabel }}$ pada taraf signifikansi $\alpha=0,05$.

Model regresi linear ganda $Y=19,61+2,25 X_{1}-0,61 X_{2}$ ini mengandung arti bahwa jika secara bersama-sama kemampuan awal matematika $\left(\mathrm{X}_{1}\right)$ dan motivasi kuliah $\left(\mathrm{X}_{2}\right)$ di tingkatkan 1 unit/ skor maka hasil belajar statistika dasar (Y) mahasiswa STAIN Manadocenderung meningkat masing-masing sebesar 2,25 unit dan 0,61 unit pada konstanta a0 sebesar 19,61.

Penghitungan koefisien korelasi ganda antara kemampuan awal matematika $\left(\mathrm{X}_{1}\right)$ dan motivasi kuliah $\left(\mathrm{X}_{2}\right)$ dengan hasil belajar statistika dasar mahasiswa STAIN Manado menghasilkan koefisien korelasi $\left(\mathrm{R}_{\mathrm{y} .12}\right)$ sebesar 0,85 . Hasil ini menunjukan bahwa hubungan antara kemampuan awal matematika $\left(\mathrm{X}_{1}\right)$ dan motivasi kuliah $\left(\mathrm{X}_{2}\right)$ secara bersama-sama dengan hasil belajar statistika dasar (Y) mahasiswa STAIN Manado positif dan sangat kuat. Temuan ini membenarkan hipotesis penelitian yang di ajukan yaitu terdapat hubungan positif antara keampuan awal matematika dan motivasi kuliah secara bersama-sama dengan hasil belajar statistika dasar mahasiswa STAIN Manado. Dengan kata lain, makin tinggi kemampuan awal matematika dan motivasi kulia mahasiswa, maka makin tinggi pula hasil belajar statistika dasar.

Hubungan ini ternyata merupakan hubungan yang sangat berarti. Hal ini sesuai dengan hasil pengujian signifikansi (keberartian) koefisien korelasi ganda melalui uji F. Hasil penghitungan di peroleh nilai $\mathrm{F}_{\text {hitung }}$ sebesar 61,032. Nilai $\mathrm{F}_{\text {tabel }}$ pada taraf 
signifikansi $\alpha=0,05$ dengan derajat bebas (db) pembilang 2 dan derajat bebas $(\mathrm{db})$

penyebut 47 sebesar 3,19. Karena nilai $F_{\text {hitung }}>\mathrm{F}_{\text {tabel }}$ maka $\mathrm{H}_{0}$ di tolak. Ini berarti penerima $\mathrm{H}_{1}$ yang menyatakan bahwa model regresi ganda $\mathrm{Y}=19,61+2,25 \mathrm{X}_{1}-$ $0,61 \mathrm{X}_{2}$ signifikan. Model regresi ini ternyata signifikan karena nilai $\mathrm{F}_{\text {hitung }}>\mathrm{F}$ tabel pada taraf signifikan $\alpha=0,05$

Hubungan positif, sangat kuat, dan sangat berarti secara bersama-sama antara kemampuan awal matematika $\left(\mathrm{X}_{1}\right)$ dan motivasi kuliah $\left(\mathrm{X}_{2}\right)$ dengan hasil belajar statistika dasar (Y) pada mahasiswa STAIN Manado ini menghasilkan koefisien determinasi $\left(\mathrm{R}_{\mathrm{Y} 12}{ }^{2}\right)$ sebesar $(0,85)^{2}=0,722$. Hal ini berarti $72,2 \%$ variasi yang terjadi pada hasil belajar statistika dasar (Y) dapat di jelaskan secara bersama-sama oleh variasi kemampuan awal matematika $\left(\mathrm{X}_{1}\right)$ dan motivasi kuliah $\left(\mathrm{X}_{2}\right)$ melalui model regresi $\mathrm{Y}=19,61+2,25 \mathrm{X}_{1}-0,61 \mathrm{X}_{2}$. dengan kata lain bahwa kontribusi yang di sumbangkan secara bersama-sama oleh variabel kemampuan awal matematika dan motivasi kuliah terhadap hasil belajar statistika dasar mahasiswa STAIN Manado sebesar $72,2 \%$.

\section{Pembahasan}

\section{Hubungan antara kemampuan awal matematika dengan hasil belajar statistika dasar}

Berdasarkan hasil analisis di peroleh model regresi antara kemampuan awal matematika dengan hasil belajar statistika dasar adalah $\mathrm{Y}=80,039-0,058 \mathrm{X}_{1}$. Model regresi ini menunjukan bahwa setiap kenaikan satu skor kemampuan awal matematika akan di ikuti oleh naiknya skor hasil belajar statistika dasar sebesar 80 , 097 unit pada konstanta 80,039. Dengan kata lain makin tinggi kemampuan awal matematika mahasiswa, makin tinggi pula pencapaian hasil belajar statistika dasar.

Kemampuan awal matematika merupakan keterampilan dan kecakapan matematika yang dimiliki mahasiswa yang dapat di gunakan dalam memahami dan memecahkan masalah pada konsep statistik. Kecakapan dan keterampilan ini telah di 
peroleh mahasiswa pada jenjang pendidikan sebelumnya. Keterampilan matematika yang berkaitan dengan konsep statistika dasar adalah keterampilan dalam melakukan operasi hitung bilangan bulat ( penjumlahan, pengurangan, perkalian, dan pembagian).

Mahasiswa yang memiliki kemampuan awal matematika yang tinggi (memadai) maka akan mudah memecahkan masalah / soal pada konsep statistika dasar sehingga pada akhirnya mereka bisa mencapai hasil belajar sesuai yang di harapkan serta akan lebih mudah mempelajari materi selanjutnya. Hal ini sesuai dengan pendapat Dick and Carrey bahwa kemampuan awal (entery behavior) merupakan pengetahuan dan keterampilan yang harus dimiliki mahasiswa sebelum ia melanjutkan ke jenjang berikutnya.

Jadi dengan demikian, mahasiswa yang memiliki kemampuan awal matematika yang tinggi maka hasil belajar statistika dasar mereka makin tinggi pula. Ini berarti bahwa ada hubungan positif antara kemampuan awal matematika mahasiswa dengan capaian hasil belajar statistika dasar. Hal ini sesuai dengan temuan penelitian yang menunjukan bahwa nilai koefisien korelasi antara kemampuan awal matematika mahasiswa dengan hasil belajar statistika dasar sebesar 0,865. Nilai koefisien korelasi ini bermakna bahwa hubungan antara kemampuan awal matematika dengan hasil belajar statistika dasar mahasiswa positif dan sangat kuat. Kepositifan dan kekuatan hubungan ini memberikan kontribusi sebesar $82,81 \%$ bagi peningkatan hasil belajar statistika dasar. Dengan kata lain kemampuan awal matematika mahasiswa memberikan kontribusi sebesar $82,81 \%$ bagi peningkatan hasil belajarmahasiswa pada konsep statistika dasar.

Jadi, untuk itu dosen perlu menelusuri dan membangkitkan kembali kemampuan awal matematika yang di miliki setiap mahasiswa ketika akan memulai proses perkuliahan statistika dasar terutama pada konsep-konsep yang melibatkan operasi hitung bilangan bulat dalam matematika. Salah satu cara yang dapat di lakukan dosen 
dalam menelusuri kemampuan awal matematika mahasiswa adalah melalui tes awal (pre tes) yang di berikan sebelum proses perkuliahan di mulai. Dan, untuk membangkitkan kembali ingatan mahasiswa terhadap konsep matematika dapat dilakukan dengan cara mengulang kembali konsep mmatematika itu di sela-sela perkuliahan atau memberikan pembekalan ulang di luar jam perkuliahan yang dapat dilakukan secara individu ataupun kelompok.

\section{Hubungan antara motivai kuliah dengan hasil belajar statistika dasar}

Berdasarkan hasil analisis di peroleh model regresi linear antara motivasi kuliah dengan hasil belajar statistika dasar adalah : $\mathrm{Y}=76,40+0,0038 \mathrm{X}_{2}$. Model regresi linear ini mengandung arti bahwa setiap kenaikan satu skor motivasi kuliah akan di ikuti oleh kenaikan skor hasil belajar statistika dasar sebesar 76,40038 unit pada konstanta 76,40. Dengan kata lain, makin tinggi otivasi kuliah mahasiswa, maka makin tinggi pula hasil belajar statistika dasar.

Motivasi kuliah merupakan daya penggerak / kekuatan yang mendorong mahasiswa untuk melakukan aktivitas kulah dalam upaya mencapai hasil belajar yang maksimal. Kekuatan ini dapat berasal dari dalam diri mahasiswa misalnya: hasrat, keinginan untuk mencapai hasil belajar yang maksimal ; dan dapat pula berasal dari luar dirinya misalkan: penghargaan, lingkungan belajar yang kondusif, proses pembelajaran yang menarik.

Mahasiswa yang memiliki motivasi kuliah yang tinggi tentu akan senantiasa aktif mencari informasi yang terkait dengan apa yang sedang dipelajari, memiliki rasa tanggung jawab, percaya diri, dan mampu mengaktualisasikan diri. Semua ini dilakukan sengan tujuan untuk mendapatkan hasil belajar yang maksimal. Hal ini sesuai dengan pendapat Alderfer ${ }^{12}$ (dalam Nashar) bahwa motivasi kuliah adalah suatu dorongan internal dan eksternal yang menyebabkan seseorang bertindak dan

12 Nashar, Peranan Motivasi dan Kemampuan Awal Dalam Kegiatan Pembelajaran. ( Jakarta: Delia Press.2004) h, 42 
berbuat untuk mencapai tujuan, sehingga perubahan tingkah laku pada diri seseorang di harapkan terjadi. Mahasiswa yang memiliki motivasi kuliah tinggi senantiasa terdorong untuk berusaha mengerjakan setiap tugas yang di erikan dosen, berusaha mencari solusi dari setiap permasalahan yang di hadapi, berusaha mencari tambahan materi kuliah melalui media lain, tidak cepat puas dengan prestasi yang di peroleh, aktif berperan selama proses perkuliahan agar bisa mencapai hasil belajaryang lebih baik dari sebelumnya. Jadi dengan demikian, mahasiswa yang memiliki motivasi kuliah yang tinggi maka hasil belajarnya pada konsep statistika dasar akan makin tinggi. Ini berarti bahwa ada hubungan positif antara motivasi kuliah mahasiswa dengan capaian hasil belajar statistika dasar-nya. Hal ini sesuai dengan temuan penelitian yang menunjukan bahwa nilai koefisien korelasi antara motivasi kuliah mahasiswa dengan hasil belajar statistika dasar khususnya pada konsep statistika dasar sebesar 0,706. Nilai koefisien korelasi ini bermakna bahwa hubungan antara motivasi kuliah dengan hasil belajar statistika dasar mahasiswa positif dan kuat. Kepositifan dan kekuatan hubungan ini ternyata memberikan kontribusi sebesar $49,84 \%$ bagi peningkatan hasil belajar konsep statistika dasar.

Mengingat motivasi kuliah mahasuswa ini memberikan kontribusi yang cukup berarti bagi peningkatan hasil belajar statistika dasar maka dalam kegiatan perkuliahan, dosen perlu mendorong berkembangnya motivasi kuliah mahasiswa. Salah satu upaya yang dapat di lakukan adalah melaksanakan perkuliahan yang berbasis pada mahasiswa belajar ( student learning), misalnya menerapkan model perkuliahan yang bberkembang dewasa ini seperti model perkuliahan berbasis masalah, kooperatif dan sebagainya agar mahasiswa termotivasi untuk ikut berpartisipasi dalam kuliah sehingga hasil belajarnya akan lebih baik.

Persentasi variasi hasil belajar statistika dasar mahasiswa yang dapat di jelaskan oleh motivasi kuliah $(49,84 \%)$ lebih kecil bila di bandingkan dengan persentasi variasi yang dapat di jelaskan oleh kemampuan awal matematika $(82,81 \%)$. Hal ini dapat terterima secara logika, sebab faktor kemampuan awalmatematika berkaitan 
langsung dengan konsep statistika dasar, sehingga meskipun motivasi kuliah mahasiswa tinggi tetapi memiliki kemampuan awal matematika renda maka capaian hasil belajar yang maksimal belum tentu akan dapat di capai.

Namun, kemampuan awal matematika mahasiswa akan semakin tinggi jika di dukung oleh motivasi kuliah yang tinggi pula. Karena itu motivasi kuliah mahasiswa ini perlu di tingkatkan karena memberikan hubungan yang kuat dan positif terhadap hasil belajar statistika dasar.

\section{Hubungan secara bersama-sama antara kemampuan awal matematika dan motivasi kuliah dengan hasil belajar statistika dasar}

Berdasarkan hasil analisis di peroleh model regresi ganda antara kemampuan awal matematika dan motivasi kuliah secara bersama-sama dengan hasil belajar statistika dasar adalah: $\bar{Y}=19,61+2,25 \mathrm{X}_{1}-0,61 \mathrm{X}_{2}$. Model regresi ini menunjukan bahwa jika skor kemampuan awal matematika dan motivasi kuliah secara bersama-sama di naikan satu unit / satuan maka skor hasil belajar statistika dasar cenderung naik sebesar 2,25 unit dan 0,61 unit pada konstanta sebesar 19,61. Dengan kata lain, makin tinggi kemampuan awal matematika dan motivasi kuliah mahasiswa, maka makin tinggi pula hasil belajar statistika dasar yang di capai.

Kemampuan awal matematika merupakan keterampilan dan kecakapan mahasiswa tentang fakta, prinsip, dan aturan dalam matematika yang terkait dengan materi statistika dasar. Kemampuan di maksud adalah keterampilan mengaplikasikan operasi hitung bilangan bulat dan operasi hitung dalam konsep statistika dasar. Keterampilan ini telah di peroleh mahasiswa pada jenjang pendidikan sebelumnya atau pada perkuliahan sebelumnya.

Mahasiswa yang memiliki kemampuan awal matematika yang tinggi akan mudah menyerap materi statistika dasar yang di ajarkan dosen dan mudah memecahkan masalah yang berkaitan dengan materi tersebut. Dengan demikian, 
mahasiswa yang memiliki kemampuan awal matematika yang tinggi akan dapat mencapai hasil belajar statistika dasar yang tinggi pula.

Kemampuan awal matematika yang tinggi di dukung oleh motivasi kuliah yang tinggi tentu akan lebih meningkatkan hasil belajar mahasiswa pada konsep statistika dasar. sebab, mahasiswa yang memiliki motivasi kuliah yang tinggi akan senantiasa berusaha dan memiliki hasrat untuk mempelajari materi yang di berikan dosen, aktif berperan dalam perkuliahan, bertanggung jawab terhadap tugas yang di berikan dosen, senantiasa ingin berprestasi, dan tidak cepat berputus asa dalam menghadapi masalah.

Motivasi mahasiswa akan semakin berkembang apabila dalam kegiatan perkuliahan dosen menyajikan suasana perkuliahan yang membuat mahasiswa merasa sengang, melibatkan mahasiswa, sehingga mahasiswa termotivasi untuk aktif berperan dalam kegiatan perkuliahan.dengan kata lain dosen dalam kegiatan perkuliahan senantiasa menjadikan mahasiswa sebagai subyek belajar dan bukan semata-mata untuk pencapaian terselesaikannya materi. Salah satu upaya yang dapat di lakukan dosen adalah melaksanakan perkuliahan berbasis model perkuliahan yang dewasa ini sedang berkembang seperti model perkuliahan berbasis masalah, kooperatif, dan sebagainya.

Jadi dengan demikian, terdapat hubungan yang positif antara kemampuan awal matematika dan motivasi kuliah dengan hasil belajar statistika dasar mahasiswa.hal ini sesuai dengan temuan penelitian yang menunjukan bahwa nilai koefisien korelasi antara kemampuan awalmatematika dan motivasi kuliah secara bersama-sama dengan hasil belajar statistika dasar sebesar 0,85.

Nilai koefisien korelasi ini memberikan arti bahwa hubungan antara kemampuan awal matematika dan motivasi kuliah dengan hasil belajar statistika dasar positif dan sangat kuat. Kepositifan dan kekuatan hubungan ini ternyata memberikan kontribusi sebesar 72,2\% terhadap hasil belajar statistika dasara mahasiswa. Dengan kata lain kemampuan awal matematika dan motivasi kuliah 
mahasiswa secara bersama-sama memberikan kontribusi sebesar 72,2\% bagi peningkatan hasil belajar statistika dasar mahasiswa.

Kontribusi ini secara teori dapat di benarkan karena aspek yang terkait dengan hasil belajar mahasiswa tidak hanya di tentukan oleh tingginya kemampuan awal dan motivasi kuliah mahasiswa.

Masih banyak aspek lain yang berkaitan dengan motivasi kuliah mahasiswa di antaranya kemampuan dosen mengajar, fasilitas yang tersedia, peran orang tua, lingkungan perkuliahan, dan sebagainya. Dengan demikian ada sekitar 27,8\% hasil belajar statistika dasar mahasiswa yang di tentukan oleh faktor lain.

\section{Penutup}

Berdasarkan temuan dan pembahasan hasil penelitian maka dapat di simpulkan hal-hal berikut.

1. Terdapat hubungan positif terhadap kemampuan awal matematika dengan hasil belajar statistika dasar mahasiswa STAIN Manado. Artinya, akin tinggi kemampuan awal matematika mahasiswa maka makin tinggi pula capaian hasil belajar statistika dasar. Hal ini di dukung oleh kontribusi yang di sumbangkan variabel kemampuan awal matematika terhadap pencapaian hasil belajar statistika dasar mahasiswa sebesar $82,81 \%$.

2. Terdapat hubungan positif antara motivasi kuliah dengan hasil belajar statistika dasar mahasiswa STAIN Manado. Artinya, makin tinggi motivasi kuliah mahasiswa, maka makin tinggi pula pencapaian hasil belajar statistika dasar. Hal ini di dukung oleh kontribusi yang di sumbangkan variabel motivasi kuliah terhadap pencapaian hasil belajarstatistika dasar mahasiswa sebesar 49,84\%

3. Terdapat hubungan positifsecara bersama-sama antara kemampuan awal matematika dan motivasi kuliah dengan hasil belajar statistika dasar mahasiswa STAIN Manado. Artinya, makin tinggi kemampuan awal matematika dan motivasi kuliah mahasiswa secara bersama-sama maka 
makin tinggi pencapaian hasil belajar statistika dasar. Hal ini di dukung oleh kontribusi yang di sumbangkan secara bersama-sama dari variabel kemampuan awal matematikadan motivasi kuiah terhadap pencapaian hasil belajar statistika dasar mahasiswa sebesar 72,2\%. 


\section{Daftar Pustaka}

Arikunto, Suharsimi. 2006. Prosedur Penelitian Suatu Pendekatan Praktek,(Jakarta: Rhineka Cipta)

Asrori,Mohamad,2007. Psikologi Pembelajaran.(Bandung: Wacana Prima)

Bloom, Benyamin, 1979 Taxonomi of Educational Objective, London: Longman

Dick, Walter and Carrey Lou,1990. The Systematic Design of Instruction. New york : Harper Collins Publishers.

Fraenkel,Wallen. 1993. How to Design and Evaluate Research; New York: Mc GrawHill Inc.

Gafur.Abdul,1989 Desain Instruksional Solo: Tiga Serangkai.

Good, Thomas L, and Jere E. Brophy,1990 , Educational Psychologi, A. Realistic Aproach, New York: Longman

Hamalik,Oemar,2001. Proses Belajar Mengajar. Bandung: Bumi Aksara

Hudoyo, Herman.1988. Strategi Belajar Mengajar Matematika.Malang: IKIP Malang Muncarno,2007. Analisis Latar Belakang Kemampuan Awal Matematika Mahasiswa PGSD FKIP UNILA. Tesis: PPs Universitas Negeri Lampung

Nashar,2004. Peranan Motivasi dan Kemampuan Awal Dalam Kegiatan Pembelajaran. Jakarta: Delia Press. 
Reigeluth, Charles M, 1983 Instructional Design Theories and Models: An Overview of Their Current Status. London: Lawrence Erlbaum Associates Publishers Hillsdale, New Jersey.

Sagala, Syaiful, 2003. Konsep dan Makna Pembelajaran. Bandung: Alfabeta.

Slameto.2003. Belajar dan Faktor-faktor yang Mempengaruhinya. Jakarta: Rineka Cipta,

Sudjanah, 2002. Metode Statistika. Bandung: Tarsito. . 2002. Penilaian Hasil Proses Belajar Mengajar (Bandung: PT Remaja Rosdakarya

Sugiono, 2007 Statistika Untuk Penelitian. Bandung: ALFABETA

Uno B. Hamzah, 2008. Desain Pembelajaran, Gorontalo Nurul Jannah

Widyastuti, Eliza. 2008, Pengaruh Kemampuan Awal Motivasi Belajar, dan Kecemasan Menghadapi Tes Matematika terhadap Prestasi Belajar Matematika Siswa SMA As-Salam Sukoharjo

Yamin,Martinis 2009 Strategi Pembelajaran Berbasis Kompetensi, Jakarta: Gaun Persada Press 